
cultures

Les cahiers de l'Acedle

\title{
La recherche libre en danger
}

Chercheur libre, Chercheuse libre et Camille Noûs

\section{OpenEdition}

\section{Journals}

Édition électronique

URL : http://journals.openedition.org/rdlc/7242

DOI : $10.4000 /$ rdlc.7242

ISSN : 1958-5772

Éditeur

ACEDLE

\section{Référence électronique}

Chercheur libre, Chercheuse libre et Camille Noûs, « La recherche libre en danger », Recherches en didactique des langues et des cultures [En ligne], 17-1 | 2020, mis en ligne le 06 avril 2020, consulté le 18 avril 2020. URL : http://journals.openedition.org/rdlc/7242 ; DOI : https://doi.org/10.4000/rdlc.7242

Ce document a été généré automatiquement le 18 avril 2020

\section{(c) (1) $\odot$}

Recherches en didactique des langues et des cultures is licensed under a Creative Commons AttributionNonCommercial-NoDerivatives 4.0 International License 


\section{La recherche libre en danger}

Chercheur libre, Chercheuse libre et Camille Noûs

RÉSUMÉS

Article ? Mirage.

INDEX

Mots-clés : revues en lutte, université ouverte, sciences en danger, RDLC 